\title{
Competitiveness Assessment of the Fats and Oils Sector in Colombia in 2019: Analysis based on Financial Indicators
}

\author{
OSCAR IVAN VASQUEZ-RIVERA \\ Facultad Ciencias Económicas y Empresariales \\ Universidad Santiago de Cali \\ Calle 5 \# 62-00 Cali \\ COLOMBIA \\ CARMEN ALICIA DIAZ-GRAJALES \\ Facultad Ciencias Económicas y Empresariales \\ Universidad Santiago de Cali \\ Calle 5 \# 62-00 Cali \\ COLOMBIA
}

\begin{abstract}
This study assesses the competitiveness of the fats and oils sector in Colombia in 2019 using a peer group approach. The analysis is applied to 13 companies in the sector classified as individual small- and medium-sized enterprises. The main findings were developed considering the reports of the Superintendence of Companies in 2020. The methodology used is a competitiveness analysis supported by financial indicators and the data envelopment analysis under the Charnes, Cooper \& Rhones-CCR- model, considering the value of assets and revenues as input and profitability indexes (operating margin, return on assets, and return on equity) as output. The companies that are efficient and should be role models were identified. The main findings were the low attractiveness of the sector with 0.253 (it should be greater than 1 and grow over time), the business success level according to which a company located in the Department of Casanare is the leader, and the relationship between the variables that reflects an average technical efficiency of 0.7162 (on a scale of 0 to 1 ). Of all the companies, three are referents for the achievement of technical efficiency owing to the best use of the model input resources
\end{abstract}

Key-Words: - Competitiveness, financial indicators, sector analysis, DEA

Received: March 26, 2021. Revised: November 15, 2021. Accepted: November 27, 2021. Published: December 14, 2021.

\section{Introduction}

At the end of 2019, the economic growth in 23 of the 33 countries of Latin America and the Caribbean slowed down (Economic Commission for Latin America and the Caribbean [ECLAC] 2019). Moreover, the ECLAC indicated there is a low aggregate external demand as well as society's unmet needs and dissatisfaction in different countries evidenced through protest marches and demonstrations that hindered economic development [1].

Business activity and, especially, industrial activity are drivers of national economic development in Colombia. Based on provisional calculations, the National Government Department of Planning GDP recorded a $3.1 \%$ growth in 2019 as compared to 2018 (see Fig. 1). Of the 12 branches that comprise the GDP, only construction suffered a $1.3 \%$ decrease. The oils and fats sector, with 51 facilities engaged in the extraction, refining, and manufacture of margarines, represents $9 \%$ of the GDP and is the fifth largest producer within the agribusiness macrosector. Palm oil is one of the country's bets for the growth of this sector, which has 5.2 million hectares with high potential for planting oil palm sustainably [2]. 


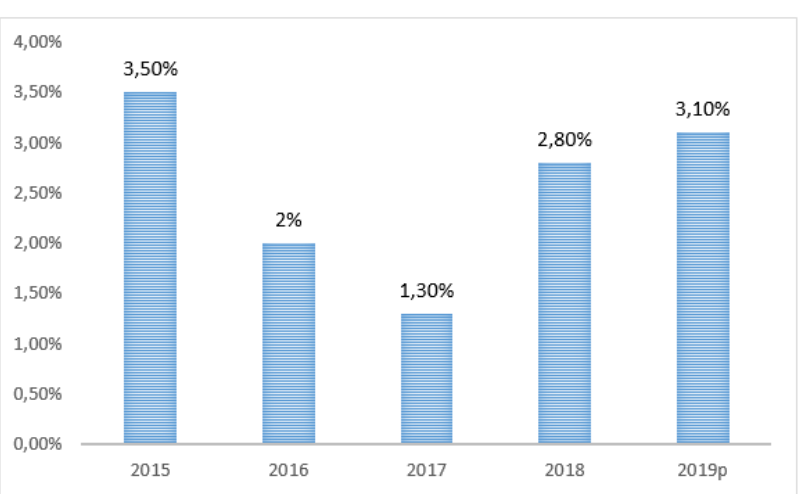

Fig. 1: GDP Growth Rate in Colombia. Source: Prepared by the authors based on data from the DANE (2021)

In the third quarter of 2020, the GDP of the animalvegetable oils and fats production sector rose by $5.7 \%$ over the same period last year. Companies expect to remain in the domestic market, as well as compete in international markets. Colombia is the world's fourth largest palm oil producer. Exports of oils and fats increased by $11.4 \%$ between January and September 2020, reaching USD 471 million [3].

Approximately 4,200 small-scale palm producers are part of the total of 6,000 producers that concentrate the productive dynamics of palm oils in Colombia. Thus, this sector became one of the major promoters of social and economic inclusion of the Colombian agricultural sector (see Fig. 2). By 2018, the sector accounted for approximately 170,000 direct and indirect jobs in the palm oil production activity, in a ratio of 2.5 indirect jobs and 1 formal direct job for every 7.5 hectares of oil palm planted [4].

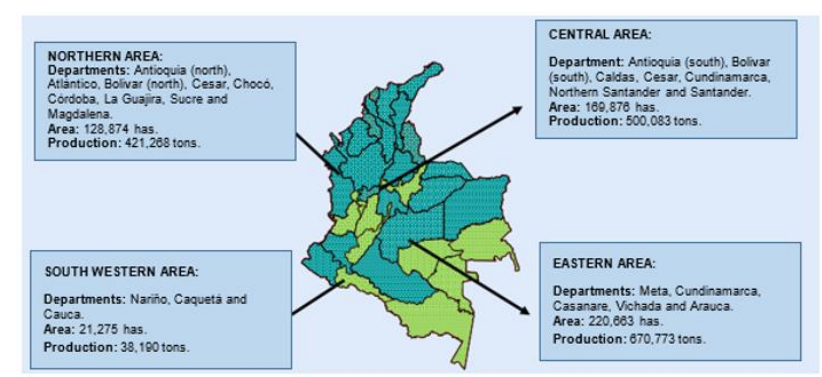

Fig. 2: Palm Oil Production in Colombia in 2019. Source: Ministry of Agriculture and Rural Development (2020)

Through Executive Order No. 2354 of 1996 and based on Law No. 101 of 1993, the Colombian Federation of Palm Oil Growers, consolidated the price stabilization fund for palm oil, palm kernel, and derivative products. FEDEPALMA's intention was to contribute to the stabilization of competitive conditions for trading palmists and palm oils in Colombia [5].

Thus, this article presents an analysis of the competitiveness of 13 companies in the oils and fats subsector in Colombia, representing the 4 production areas: north, central, west, and east. The following figure shows the evolution of production per area.

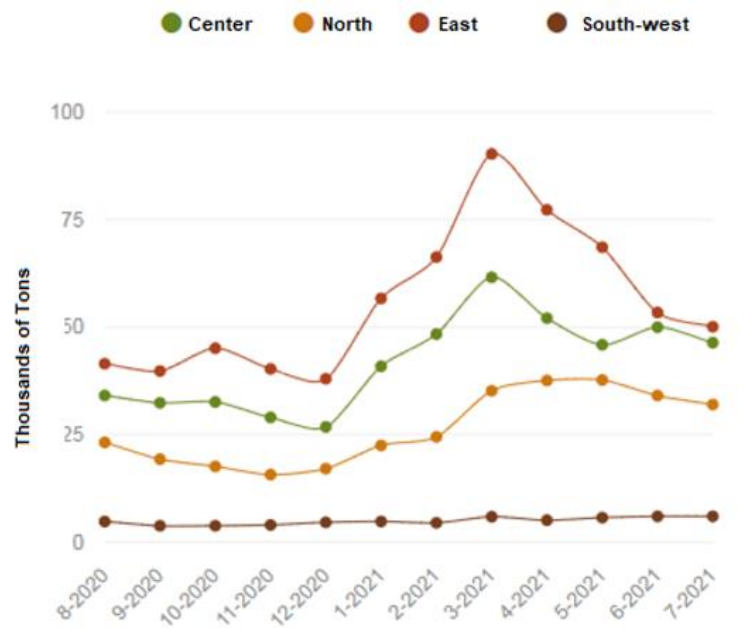

Fig. 3: Evolution of Oil Production per Area. Source: FEDEPALMA (2019)

Competitiveness refers to the comparison between companies in the context wherein they are operating for the purpose of measuring value creation and generation through corporate strategies aimed at promoting greater economic gain within a context of permanent competition at micro, meso, and macro levels. The goal of competitive analysis at the sectoral level is focused on discovering the tools and internal decisions that facilitated achieving competitiveness and the origin of the dynamics that enhance profitability. On the contrary, it is clear that this analysis does not seek to recognize the attractiveness of the sector and the participant companies. In conclusion, the companies that create value foster a sustainable competitive environment and contribute to regional economic development $[6,7]$.

Microenterprises and small- and medium-sized enterprises (SMEs) are key to Colombia's industrial structure and create a large number of jobs. However, they are less competitive than large Colombian companies. To overcome this hurdle, including SMEs in production chains complements the scale economies of large companies, favoring the creation of productive agglomerations and social inclusion, as well as enhancing the profitability of 
microenterprises and lessening their insolvency risk [8].

Companies' performance in the market is determined by productivity, which is the input/output ratio. The maximum efficiency achieved with the combination of existing resources is represented by the production possibilities frontier.

Only oligopolistic sectors, characterized by great market power, ensure that resources and incentives are available for firms to undertake major technological projects and improvements to reach high levels of innovation, research, and development [9].

High-performing companies that achieve a dominant position in the competitive environment may be identified by focusing on the characteristics of the sector and by adopting the theory of capabilities and resources $[10,11]$.

Competitiveness is assessed based on financial indicators through the estimation of the technical efficiency employing the data envelopment analysis (DEA). Under this method, the business success indicator is determined for the 13 productive units based on the financial information registered with the Superintendence of Companies of Colombia under code CIUU 1030, "Production of oils and fats of animal and vegetable origin" for 2018 and 2019. The technical efficiency score of each company considered a Business Unit or Decision Market Unit (DMU) is calculated.

\section{Literature Review}

The first concept explained below is financial planning. Consider financial planning as a very useful business tool for evaluating financial results for internal purposes, such as internal and external projects like negotiations, investments, and decision making. As it is an integration tool, it easily adapts to any type of investment and supports the creation of long-term sustainable companies, as it helps visualize the quantitative results of the different organizational areas, making it possible to take action to strike an economic balance across business levels, successfully addressing contextual challenges and changes [12].

Also, strategic and comprehensive financial planning is the basis for making right decisions as it makes it possible to predict future economic, accounting and financial behaviors and consequences.

In accordance with the above, Castro and Castro argue that

"Financial planning establishes the method for achieving goals; it also represents the basis for the company's overall economic activity. In addition, it aims at foreseeing future needs so that present needs can be met in accordance with a specific goal, which is set in the company's actions" (page 7) [13].

In this sense, Rojo, considers value-based financial planning as a managerial tool that allows one to anticipate the financial results of the decisions that will be made concerning the direction of the company's value and is therefore a preassessment of the managers' potential decisions considering the company's long-term strategies [14].

Therefore, value-based financial management is a new way of directing business management focused on the creation of economic value, i.e., the creation of wealth for all those involved in the company.

Economic value is created by establishing a set of strategies with specific financial and nonfinancial goals that must be integrated into the business management process.

It is essential to make decisions based on reliable information derived from a system capable of providing retrospective and prospective data on the company's status, as well as measuring the company's performance to ensure good value management. Hence, companies achieve their goals to the extent that they have an efficient generation and balanced allocation of value [15].

For this reason, companies should draft reports highlighting the elements, processes and tools that contributed to the establishment and identification of the value creation strategy adopted in the company. The ultimate goal is to evaluate the management's ability to create wealth for the company.

Another fundamental concept in this research is competitiveness. For companies to gain a competitive edge they must carry out strategic plans to be more efficient and make or offer products and services different from those of competitors, thus creating a unique value offer preferred by 
customers. This can only be done by looking at the company in a systemic manner [16].

The value chain is a model that fixes the time frames and costs of the company's main activities to assign the highest corresponding value to each one, cutting costs and maximizing the profit margin between what the customer is willing to pay and the production cost.

Understanding the value chain is key to holding a competitive advantage as it separates the company's most relevant activities and those that are strategically feasible to understand cost integration and the potential bases of market differentiation.

In essence, Porter believes that

"Competitive advantage comes from the value a company manages to create for its customers. It can translate into prices lower than those of competitors, even providing equivalent benefits or offering special benefits that more than compensate for a higher price" (page 43) [17].

In line with the aforementioned approaches, the authors indicates that an organization's level of competitiveness can be attained according to several factors, among which the management strategy is essential, specifically the managers' decisionmaking capacity and risk management method [18].

Other authors state that competitiveness is the result of the contextual conditions as well as the entrepreneur's managerial skills to differentiate themselves from competitors. Thus, competitiveness allows a company to become successful when it finally manages to develop and deliver to the market products and services with characteristics and qualities comparable or superior to those of the competition [19].

Therefore, it may be concluded that competitiveness depends on the companies' internal structure of organization and capacity to produce more than competitors, thus covering different areas.

Finally, another important concept for the development of this research is Production Possibility Frontiers (PPF). Other authors define PPF as the quantity of goods that can be produced synchronously and efficiently with the productive and technological resources available over a period [20].
The goal is to derive PPFs for final goods using a procedure very similar to that of Savosnik. In his research, he discusses the construction of the PPF in the case of two goods that are inputs and primary factors simultaneously. Finally, he makes an analytical generalization of the result of the previous case, making a small digression on the possible biases displayed in the empirical estimations used by the model. This type of procedure is applied in this study [21].

On the contrary, other authors explains the concept of efficiency associated with PPF and the reasons that can cause shifts in PPF. Efficiency involves using all available resources and technology in the best possible way. The PPF graph shows an economy's possible combinations of production if resource use is streamlined, as it separates efficient points from inefficient ones [22].

Thus, some authors argues that the points that lie on the PPF and use all the factors available to the economy, both material and technological, illustrate combinations of output that are efficient, while the points that are left to the PPF or within the PPF are inefficient and account for "resource unemployment" (2011), which is the maximum waste of the resources available. Finally, there are unattainable combinations, i.e., the points that are outside the FPP, and, therefore, both material and technological resources are insufficient to reach those production levels.

For Fuster, their displacements derive from several factors such as the following:

1. A country's PPF is not fixed as the capacity to produce goods and services varies over time due to the need for improvements in technology and in the available quantity or quality of productive resources.

2. A capital increases.

3. An increase or decrease in the number of employees in the production plant.

4. The discovery of new natural resources.

To understand the development of this study, the financial indicators used for the analysis of the information and its correct interpretation, are presented below [23]:

1. Economic attractiveness of the sector (financial profitability indicator) 


\begin{tabular}{|c|c|c|}
\hline INDICATOR & FORMULA & INTERPRETA TION \\
\hline NET MARGIN & Net Benefits / Sales & Percentage of profit earned per sale \\
\hline
\end{tabular}

2. Company's commercial dynamics (leverage indicator)

\begin{tabular}{|c|c|c|}
\hline INDICATOR & \multicolumn{1}{|c|}{ FORMULA } & INTERPRETA TION \\
\hline TOTAL LEVERAGE & $\begin{array}{l}\text { Contribution Margin } \\
\text { Operating Profit }\end{array} \underbrace{\text { Operating Leverage }} \begin{array}{c}\text { Operating Profit before Taxes } \\
\text { Financial Leverage }\end{array}$ & $\begin{array}{c}\text { Representation of the ratio between } \\
\text { equity and investment }\end{array}$ \\
\hline
\end{tabular}

3. Ebitda (financial diagnostic indicator)

\begin{tabular}{|c|c|c|}
\hline INDICATOR & FORMULA & INTERPRETATION \\
\hline EBITDA & $\begin{array}{l}\text { Operating income + Depreciation + Amortization + } \\
\text { Depreciation + Provisions }\end{array}$ & $\begin{array}{l}\text { It determines the earnings or profit } \\
\text { collected by a company, without taking } \\
\text { into account financial expenses, taxes, } \\
\text { and other expenses. In other words, it } \\
\text { determines the company's cash } \\
\text { generating capacity. }\end{array}$ \\
\hline
\end{tabular}

4. Company's operating efficiency (efficiency indicator)

\begin{tabular}{|c|c|c|}
\hline INDICATOR & FORMULA & INTERPRETA TION \\
\hline $\begin{array}{l}\text { OPERATING } \\
\text { EFFICIENCY }\end{array}$ & Operating Expenses / Net sales & $\begin{array}{c}\text { Activities carried out by a company to } \\
\text { offer a product or service }\end{array}$ \\
\hline
\end{tabular}

5. Sales productivity (productivity indicator)

\begin{tabular}{|c|c|c|}
\hline INDICATOR & FORMULA & INTERPRETATION \\
\hline \multirow{2}{*}{$\begin{array}{l}\text { SALES } \\
\text { PRODUCTVITY } \\
\text { INDEX }\end{array}$} & $\begin{array}{c}\text { Overall Productivity }=\text { Net Sales/Number of } \\
\text { Employees }\end{array}$ & $\begin{array}{l}\text { Overall Productivity: It determines by } \\
\text { how much sales must increase to justify } \\
\text { hiring an additional employee. }\end{array}$ \\
\hline & $\begin{array}{l}\text { Productivity per Employee }=\text { Individual Net } \\
\text { Sales/Number of Hours Worked per Employee }\end{array}$ & $\begin{array}{l}\text { Productivity per Employee: employees } \\
\text { with higher individual net sales for the } \\
\text { same amount of time who are more } \\
\text { productive }\end{array}$ \\
\hline
\end{tabular}

6. Company's competitive position (financial profitability indicator)

\begin{tabular}{|c|c|c|}
\hline INDICATOR & FORMULA & INTERPRETA TION \\
\hline $\begin{array}{c}\text { RETURN ON } \\
\text { EQUITY (ROE) }\end{array}$ & Net Income/Shareholders' Equity & $\begin{array}{l}\text { It reflects the return on contributions and } \\
\text { accumulated surplus, which should be } \\
\text { compared with the opportunity rate that } \\
\text { each shareholder has to evaluate their } \\
\text { investments. }\end{array}$ \\
\hline
\end{tabular}

7. Company's competitiveness (financial profitability indicator)

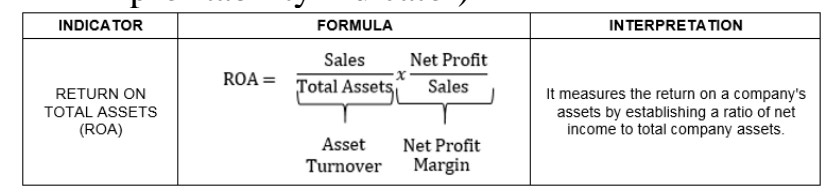

8. Company's success level

\begin{tabular}{|c|c|c|}
\hline INDICATOR & FORMULA & INTERPRETA TION \\
\hline $\begin{array}{c}\text { COMPANY'S } \\
\text { SUCCESS }\end{array}$ & (Gross Proffit / Total Assets) / Net Margin & $\begin{array}{c}\text { Profitability of the sector in which the } \\
\text { company operates }\end{array}$ \\
\hline
\end{tabular}

Finally, a review of the literature related to the fats and oils sector in Colombia reveals competitive advantages of this sector within the framework of the Pacific Alliance between 1995 and 2015. This considering that exports of products derived from this sector in Colombia were almost 5 times the exports of the same product in the Alliance for that period [24]. On the other hand, the institutional and organizational analysis of specific cases of companies related to the fats and oils sector, allows us to recognize the high capacity of the sector to guarantee not only financial competitiveness of the sector, but also environmental and social sustainability [25].

Other recent studies detail the strengthening of the fats and oils sector from the perspective of the specific analysis of the structural composition and thermal degradation of the oils that are commercially sold around the world. This perspective shows that some oils produced in different regions of Colombia are more competitive than others, but not only because of marketing variables, but also because of the chemical and natural characteristics that they offer in the composition of the product [26].

\section{Methodology and Variables}

\subsection{Methodology}

The methodology used in this study divides the analysis into two phases: The first phase is aimed at determining the strategic focus of the sector and direct competitors, while the second phase applies DEA to define DMU technical efficiency more precisely by relating input resources variables to output variables.

The unit will be efficient - it will belong to the production frontier - if it produces more of a given output without producing less of the other outputs and without consuming more inputs, or if it produces the same output with less of a given input but not more of the rest of them.

The DEA approach is a linear mathematical model proposed to measure the relative efficiency of organizational units [27].

The method establishes two basic directions to the production function [28]:

a) Input direction: It means seeking, given the level of outputs, the maximum proportional reduction in the vector of inputs while remaining within the production possibility frontier.

b) Output direction: It means seeking, given the level of inputs, the maximum proportional increase in the outputs while remaining within the production possibility frontier.

In this case, the aim is to maximize the company's profitability with the available resources of income and $\mathrm{c}$ the effect of the scale economy, the CCR 
model is implemented, which considers that study units are at constant levels of scale [29].

The model expression is the following:

$$
\begin{gathered}
\operatorname{Max} . h_{0}=\frac{\sum_{r=1}^{s} U_{r 0} Y_{r 0}}{\sum_{i=1}^{m} V_{i 0} X_{i 0}} \\
\text { s.a. }: \frac{\sum_{r=1}^{s} U_{r 0} Y_{r j}}{\sum_{i=1}^{m} V_{i 0} X_{i j}} \leq ; j=1,2, \ldots, n \\
V_{i 0}, U_{r 0} \geq 0 ; \begin{array}{l}
r=1,2, \ldots, s \\
i=1,2, \ldots, m
\end{array}
\end{gathered}
$$

The technical efficiency or productivity $h_{0}$ is equal to the weighted sum of the outputs divided by the weighted sums of the inputs, where $Y_{r 0}$ represents the amount of output obtained by the unit that is evaluated and $X_{i 0}$ represents the amount of input i, consumed by the unit what is evaluated. The subscript " 0 " refers to the productive unit, previously defined as DMU, related to the companies, whose efficiency will be evaluated. $Y_{r j}$ is the amount of " $\mathrm{r}$ " (profitability) produced by DMU "j." On the contrary, $X_{i j}$ will be the amount of input "I" used by DMU "j”; and $U_{r 0}$ and $V_{i 0}$ will be the weights assigned to each input and output related to each DMU. Therefore, the optimization will yield a set of positive values of $U_{r 0}$ and $V_{i 0}$, and the efficiency index $h_{0}$ assigned to each DMU. The $\mathrm{n}$ constraints ensure that no DMU can have an efficiency higher than unit 1 ; in turn, the weights assigned must be positive [30].

\subsection{Data and Variables}

Data are taken from the companies that are required to file accounting information with the Superintendence of Companies of Colombia. A total of 46 SMEs were found, which report under code CIUU 1030, "Production of oils and fats of animal and vegetable origin" for 2018 and 2019, and 13 were selected, seeking representativeness in Colombian production areas. To choose the companies, it is carried out randomly, taking into account the participation of companies by sector and also the cities within the region, the Andean region with a weight of $50 \%$ has 7 companies, the Caribbean region has 4 companies with a weight of $35 \%$ and the other two regions each with a single company, another criteria taking into account to choose the companies is the type of organization having a relative weight to the group of companies, as follows: eight SAS simplified joint-stock companies, four stock corporations and one limited company.

Below is the table detailing the selected companies, the cities where they are located and the information of the business structure for 2019. The companies' names are identified with the first three letters (see Table 1).

To conduct the competitiveness analysis, we initially established the economic attractiveness from the financial standpoint relating the profitability of the sector and the market. This indicator must be greater than 1 and grow over time. Another variable that is analyzed is the commercial dynamics, seeking to measure whether the increase in sales is reflected in profits, and to determine which companies' commercial processes are doing better by taking advantage of fixed operating expenses and fixed financial expenses to boost profitability. Operating efficiency is evaluated by considering the operating margin as an income variable, thus determining which company is more efficient in converting income into operating profit. For sales productivity, the profit earned by the company is related to commercial dynamics, making it possible to establish whether the market share increase is reflected in accounting profit.

Table 1. Companies selected, cities, profit, assets and liabilities

\begin{tabular}{|l|c|cc|cc|cc|}
\hline \multicolumn{1}{|c|}{ City } & Companies & \multicolumn{2}{c|}{ Profit } & \multicolumn{2}{c|}{ Assets } & & Liabilities \\
\hline Bogotá & PRO & $\$$ & $30.862 .043,00$ & $\$$ & $9.457 .039,00$ & $\$$ & $4.783 .919,00$ \\
\hline Valle & SAN & $\$$ & $15.986 .072,00$ & $\$$ & $10.669 .455,00$ & $\$$ & $4.162 .182,00$ \\
\hline Atlántico & SIL & $\$$ & $26.029 .632,00$ & $\$$ & $18.748 .376,00$ & $\$$ & $6.115 .273,00$ \\
\hline Bogotá & OLE & $\$$ & $14.949 .596,00$ & $\$$ & $13.463 .286,00$ & $\$$ & $1.309 .428,00$ \\
\hline Bogotá & ALI & $\$$ & $36.109 .367,00$ & $\$$ & $11.505 .326,00$ & $\$$ & $5.959 .468,00$ \\
\hline Bogotá & ENT & $\$$ & $79.365 .071,00$ & $\$$ & $40.407 .265,00$ & $\$$ & $23.918 .090,00$ \\
\hline Bogotá & MOR & $\$$ & $24.631 .249,00$ & $\$$ & $14.581 .390,00$ & $\$$ & $5.415 .958,00$ \\
\hline Bolívar & INV & $\$$ & $12.419 .097,00$ & $\$$ & $3.467 .647,00$ & $\$$ & $2.244 .392,00$ \\
\hline Casanare & ZOM & $\$$ & $54.144 .506,00$ & $\$$ & $6.795 .771,00$ & $\$$ & $4.493 .077,00$ \\
\hline Magdalena & GRA & $\$$ & $119.996 .432,00$ & $\$$ & $88.545 .761,00$ & $\$$ & $42.638 .682,00$ \\
\hline Magdalena & DER & $\$$ & $89.947 .501,00$ & $\$$ & $61.621 .752,00$ & $\$$ & $61.233 .341,00$ \\
\hline Santander & FER & $\$$ & $63.701 .067,00$ & $\$$ & $67.598 .415,00$ & $\$$ & $37.131 .628,00$ \\
\hline Santander & NUT & $\$$ & $20.273 .967,00$ & $\$$ & $7.318 .648,00$ & $\$$ & $6.151 .529,00$ \\
\hline
\end{tabular}

Source: Prepared by the authors based on information of the Superintendence of Companies (2019)

Finally, the competitive position of the companies is measured by relating their profitability to sector profitability. Through the analysis of the peer group, the companies with strategically better results are determined, thus establishing whether they are achieving their results through turnover or margin. Finally, the companies that stand out within the peer group are displayed, and they should be considered by the best practices in financial management [31]. 
As a complement, technical efficiency is evaluated using the DEA. Table 2 shows the variables included in the model:

Table 2. Variables for the DEA application

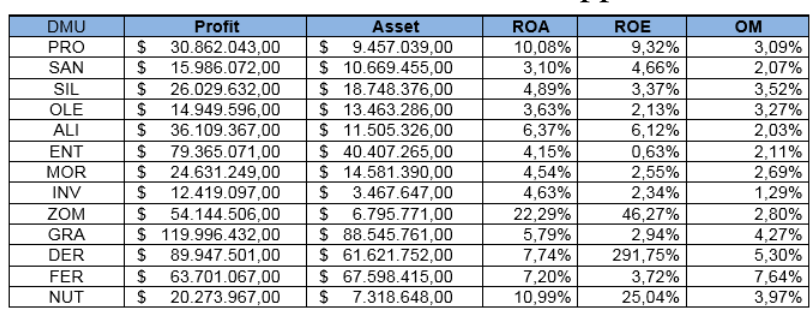

Source: Prepared by the authors based on information of the Superintendence of Companies (2019)

The data of the variables are exported from the Superintendence of Companies (2019). The program executed for the data evaluation is the Solver add-in in Excel version 2017 for DEA [32].

\section{Results and Discussion}

The subsector producing oils and fats of animal and vegetable origin is part of the Colombian industry. It does not assert great influence upon the sector; however, it has a high export potential with good opportunities in the international market, given the growth in demand for palm oils, according to data from FEDEPALMA (see Table 3) [33].

Table 3. Characterization of Oils and Fats of Animal Origin

\begin{tabular}{|c|c|c|c|}
\hline Companies & $\begin{array}{c}\% \text { Variation in } \\
\text { sales }\end{array}$ & $\begin{array}{c}\% \text { Variation in } \\
\text { profits }\end{array}$ & $\begin{array}{c}\text { Commercial } \\
\text { dynamics }\end{array}$ \\
\hline PRO & $7,52 \%$ & $19,37 \%$ & 2,58 \\
\hline SAN & $17,95 \%$ & $-137,23 \%$ & $-7,65$ \\
\hline SIL & $11,73 \%$ & $-0,94 \%$ & $-0,08$ \\
\hline OLE & $6,64 \%$ & $-35,55 \%$ & 5,35 \\
\hline ALI & $17,13 \%$ & $4187,75 \%$ & 244,5 \\
\hline ENT & $3,28 \%$ & $-12,04 \%$ & $-3,67$ \\
\hline MOR & $-4,40 \%$ & $-47,71 \%$ & 10,86 \\
\hline INV & $27,21 \%$ & $-85,95 \%$ & $-3,16$ \\
\hline ZOM & $187,01 \%$ & $-13,18 \%$ & $-0,07$ \\
\hline GRA & $25,07 \%$ & $19,78 \%$ & 0,79 \\
\hline DER & $338,24 \%$ & $-722,99 \%$ & $-2,14$ \\
\hline FER & $-11,77 \%$ & $28,19 \%$ & $-2,4$ \\
\hline NUT & $-18,65 \%$ & $-57,03 \%$ & 3,06 \\
\hline
\end{tabular}

Source: Annual survey on manufacturing by the DANE [31].

The analysis of the economic attractiveness of the sector (see Table 4) from the financial standpoint is obtained by relating the sector margin to the market margin. The net market margin is calculated from data from the Superintendence of Companies, for the manufacturing sector and the net sector margin from the 46 individual SMEs [35].
Table 4. Economic Attractiveness of the Sector

\begin{tabular}{|l|r|r|}
\hline & 2018 & 2019 \\
\hline Market net margin & $4,20 \%$ & $5,30 \%$ \\
\hline Sector net margin & $1,07 \%$ & $1,34 \%$ \\
\hline Economic attractiveness of the sector & 0,255 & 0,253 \\
\hline
\end{tabular}

Source: prepared by the authors

To qualify a sector as attractive, this indicator must be greater than one and grow over time. Sector dynamics and future expectations are measured for this purpose. If this same indicator is obtained for the 15 main companies according to the profit level from the sector report, the attractiveness for the sector for 2018 is -0.13 . The manufacturing production sector in Colombia is not attractive since its contribution margin is close to 1 in both 2018 and 2019; however, in the international market, the sector has growth potential given the opening in the markets of palm oil and its derivatives.

The commercial dynamics indicator presented in Table 5 measures the extent to which the effort to expand sales is reflected in profits. This indicator is expected to be greater than 1 and to grow. The companies achieving positive values should be analyzed to establish the reason why the increase in profits is much higher than the rise in sales and determine the factors affecting business results.

Table 5. Company's Commercial Dynamics for 2019

\begin{tabular}{|l|l|l|}
\hline \multicolumn{1}{|c|}{$\begin{array}{c}\text { Amounts in Tesos } \\
\text { Peston }\end{array}$} & \multicolumn{1}{c|}{ Sector } & \multicolumn{1}{c|}{ Industry Total } \\
\hline Industrial organizations & 103 & \\
\hline No. of facilities & 73 & 7.631 \\
\hline Total staff employed & 10.111 & 705.999 \\
\hline Permanent paid staff & 6.614 & 413.802 \\
\hline Temporary paid staff & 2.095 & 164.818 \\
\hline Staff, partners and family & 8 & 2.328 \\
\hline Agency staff & 997 & 102.412 \\
\hline Interns & 397 & 22.639 \\
\hline Salaries and wages & $\$ 223.708 .597$ & $\$ 13.888 .697 .488$ \\
\hline Social contributions & $\$ 122.757 .055$ & $\$ 8.129 .104 .438$ \\
\hline Gross production & $\$ 5.206 .997 .000$ & $\$ 273.770 .676 .953$ \\
\hline Intermediate consumption & $\$ 3.745 .829 .762$ & $\$ 177.412 .667 .983$ \\
\hline Added value & $\$ 1.461 .167 .238$ & $\$ 96.358 .008 .970$ \\
\hline Total assets & $\$ 3.496 .742 .428$ & $\$ 193.418 .769 .454$ \\
\hline Gross operating surplus & $\$ 1.114 .701 .586$ & $\$ 74.340 .207 .044$ \\
\hline Power consumption & 231.903 .420 & 16.866 .249 .545 \\
\hline Source: Prepared
\end{tabular}

Source: Prepared by the authors.

Only $50 \%$ of companies reported sales productivity (see Fig. 4) in 2019. The indicator is very close to the unit since companies fail to reflect the increase in sales in their profits. They are closer in terms of behavior, with an index between 0 and 1 . Yet, companies manage to correct the negative impacts on sales productivity in 2019 . 


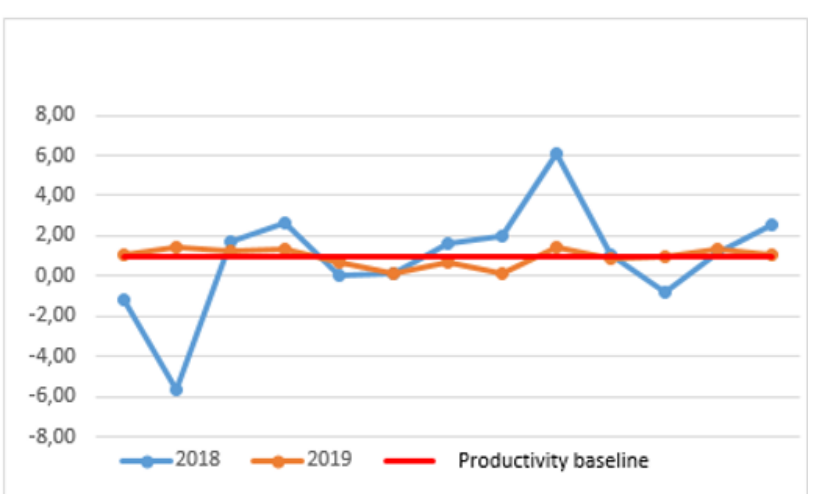

Fig. 4: Sales Productivity. Source: Prepared by the authors.

Operating efficiency determines which company is more efficient in converting revenues into operating profit. The data show how FER is the only company whose efficiency indicator is above the unit and grows in 2019 as a consequence of the operating margins presented for the two years of analysis, at $6.84 \%$ and $7.64 \%$ in 2018 and 2019, respectively. Moreover, the company reached an operating margin of $8.2 \%$ in 2020 . There are 3 companies whose operating efficiencies exceed the unit in 2019. The remainder companies analyzed fail to reach values equal to 1 , so they achieve no operating efficiency.

Table 6. Operating Efficiency

\begin{tabular}{|c|r|r|r|r|}
\hline & \multicolumn{2}{|c|}{2018} & \multicolumn{2}{|c|}{2019} \\
\hline Companies & \multicolumn{1}{|c|}{ Margin } & \multicolumn{1}{c|}{ Efficiency } & \multicolumn{1}{c|}{ Margin } & \multicolumn{1}{c|}{ Efficiency } \\
\hline PRO & $2,78 \%$ & 0,73 & $3,09 \%$ & 0,80 \\
\hline SAN & $-5,24 \%$ & $-1,38$ & $2,07 \%$ & 0,53 \\
\hline SIL & $3,97 \%$ & 1,04 & $3,52 \%$ & 0,91 \\
\hline OLE & $5,44 \%$ & 1,43 & $3,27 \%$ & 0,84 \\
\hline ALI & $0,60 \%$ & 0,16 & $2,03 \%$ & 0,52 \\
\hline ENT & $2,45 \%$ & 0,64 & $2,11 \%$ & 0,54 \\
\hline MOR & $3,72 \%$ & 0,98 & $2,69 \%$ & 0,69 \\
\hline INV & $3,16 \%$ & 0,83 & $1,29 \%$ & 0,33 \\
\hline ZOM & $8,02 \%$ & 2,11 & $2,80 \%$ & 0,72 \\
\hline GRA & $4,86 \%$ & 1,28 & $4,27 \%$ & 1,1 \\
\hline DER & $-0,09 \%$ & $-0,02$ & $5,30 \%$ & 1,37 \\
\hline FER & $6,84 \%$ & 1,8 & $7,64 \%$ & 1,97 \\
\hline NUT & $6,14 \%$ & 1,61 & $3,97 \%$ & 1,02 \\
\hline
\end{tabular}

Source: Prepared by the authors.

The competitiveness analysis (see Fig. 5) shows how company number 9 manages to maintain the level of competitiveness far higher than the other companies, with an index of 10 in 2018 and 9 in 2019, and shows the change in strategy from the profitability ratio to ROA Asset Turnover.

Figure 5 shows the decline in business success in 2019 as compared to 2018, showing that followers are moving away from the leading company.

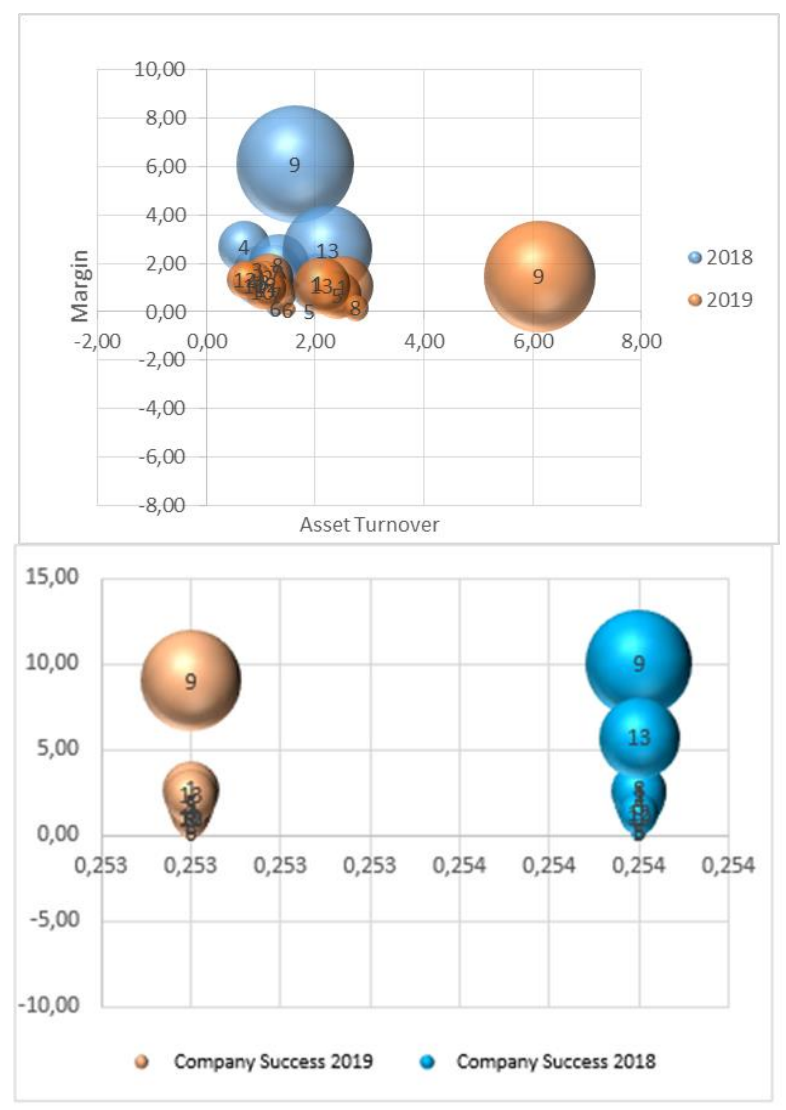

Fig. 5: Competitiveness and Company Success Source: Prepared by the authors.

The scores obtained using the DEA on the technical efficiency of each business unit are shown on the table below:

Table 7. DEA Results

\begin{tabular}{|c|r|l|}
\hline DMU Name & Efficiency Score & Efficiency Reference Group \\
\hline PRO & 0,8272 & ZOM, SAN, NUT \\
\hline SAN & 1 & \\
\hline SIL & 0,8756 & \\
\hline OLE & 0,9477 & SAN, FER \\
\hline ALI & 0,5345 & \\
\hline ENT & 0,4417 & ZOM, FER \\
\hline MOR & 0,5160 & \\
\hline INV & 0,3598 & ZOM, FER \\
\hline ZOM & 1 & \\
\hline GRA & 0,7160 & \\
\hline DER & 0,9313 & \\
\hline FER & 1 & \\
\hline NUT & 0,9880 & ZOM, FER \\
\hline
\end{tabular}

Source: Prepared by the authors.

DMUs with an evaluation of 1 are considered technically efficient; they lie on the PPFs (SAN, ZOM, FER). Companies that exceed 0.8 (PRO, SIL, OLE, DER, NUT) are also considered to be efficiently acceptable.

Figure 6 presents the most efficient companies when the model is applying (with the two input variables and the three output returns) on the external line with a score of 1 , in the lower right part it can see the most distant companies of efficiency INV, ENT, 
MOR and ALI which are at a reference level of less than $60 \%$.

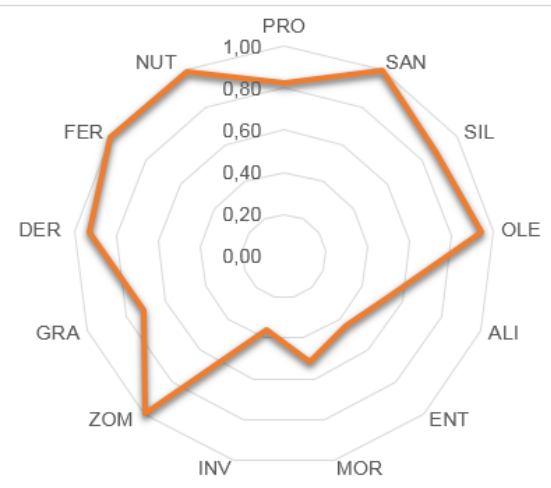

Fig. 6: Peer Group Efficiency. Source: Prepared by the authors.

Below is the graphical analysis for each of the input variables separately against the output variable Return on Asset -ROA-.

Figures 7 and 8 for the DEA, generated based on the basic CCR type, show as follows:

A (red) line of constant returns to scale (CRS) solved with the extra condition $\sum \chi j=1$ that joins the origin point of the graph with point $\mathrm{x}$, $\mathrm{y}$ (input, output) generated for the most efficient entity (FER in Fig. 7, Profits vs. ROA, and ZOM, in Fig. 8, Assets vs. ROA). This line represents the CRS envelopment surface model that assumes that an increase in inputs translates into a proportional rise in outputs.

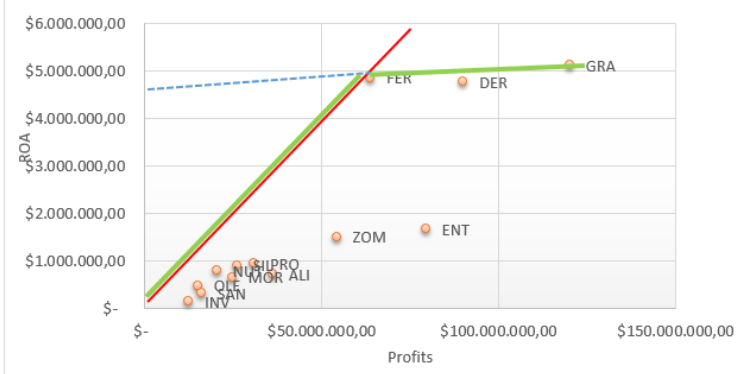

Fig. 7: Profits vs. ROA. Source: Prepared by the authors.

A (green) line that surrounds the PPF with scale and management influence which links the origin with the most efficient entity and other efficient units in management, which would be made up of the highest consecutive straight lines that join the more efficient unit with returns to scale with other units (GRA in Fig. 7 and DER, FER and GRA in Fig. 8). It represents the Variables to Scale (VRS) model, which proposes a nonproportional rise in outputs leading to increasing or decreasing returns to scale.

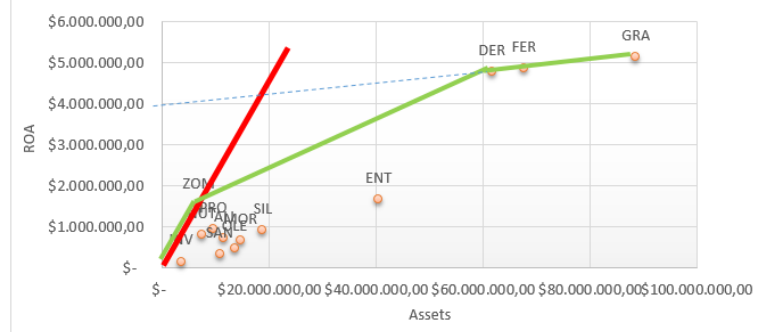

Fig. 8: Assets vs. ROA. Source: Prepared by the authors.

The efficiency calculation on this data sample considering both VRS and CRS allows one to determine the scale efficiency as the quotient between these two measures.

By determining the value of the constant $\mathrm{k}$, for the entity, crossing the line joining the entities with the $\mathrm{Y}$ axis (face line, dotted for the most efficient entities), it may be determined whether the entity has increasing returns to scale, in which case $\mathrm{k} 0<0$; whether it has of decreasing returns to scale $\mathrm{k} 0>0$; or whether it has CRS with $\mathrm{k} 0=0$. In other words, the sign of the constant $\mathrm{k}$ is the most indicative for the analysis of the companies' scale of growth.

Efficiency estimated using the VRS model, which considers variable returns, is higher than the efficiency obtained employing the CRS model, which considers constant returns to scale. If the ENT unit is analyzed, the VRS frontier (green line) marked by the best practices (FER, DER, GRAN, ZOM) is closer than the CRS frontier (red line) [36]. Firms with lower returns, whether considered under constant or scaled returns, may improve by changing their size of operations to enhance their performance and be closer to the efficient production frontiers. This is the case of ENT and the other units that are very far from the frontiers marked by the lines of the figure. If companies are very small, they may fall into increasing returns to scale; if they are very large, they may be operating with decreasing returns.

Below are profits and assets as input variables versus return on assets as the output variable. The red curve represents the best production possibilities within a set of possibilities presented by each DMU (see Fig. 9). The efficiency ratio of a production unit can be represented as: $\mathrm{EF}$ ENT = distance $\mathrm{OB}$ divided by distance OA [36]. 


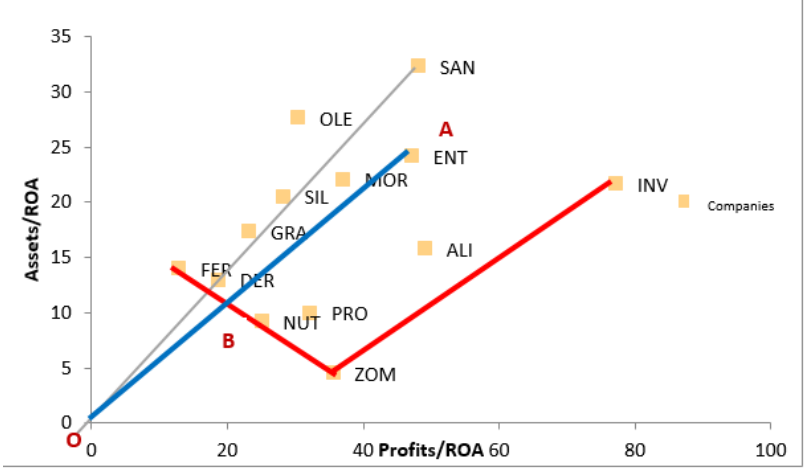

Fig. 9: Assets/ROA vs. Profits/ROA. Source: Prepared by the authors.

The FER, ZOM and INV companies are on the line of best practices in relation to the two income and asset inputs versus the Return on Assets. The other company SAN with an optimal efficiency level, is far away due by the relationship of the income variables compared to the other two outcome returns ROE and MO. It can also be seen that the INV company is being affected in efficiency by the results in the other outcomes, obtaining in the end the lowest $\chi$ with 0.3598 .

\section{Conclusion}

In conclusion, the use of financial indicators for the analysis of competitiveness allows the visualization of the behavior of the companies within the peer group selected. It clearly shows how one of the companies faced with a loss in sector attractiveness (standing at 0.253 in 2019) manages to maintain profitability and competitiveness in the market by changing the strategy from Operating Margin to Return on Assets. It is thus established that the company that attains the greatest business success is the one located in the Department of Casanare, which is ZOM company, this company also achieves technical efficiency in the Data Envelope Analysis and it could be observed that the constant returns to scale in the ratio of assets versus profitability of assets (See Fig. 8), allows it to position itself as the company with the best practice in asset profitability (See Fig. 9).

The DEA uses the CCR model, which considers that the study units (13 companies in the fats and oils sector in Colombia) are at constant levels of scale. To run the model, profits and assets are considered input variables and operating profitability, return on assets, and return on equity output variables. Three companies achieved a technical efficiency $\chi=1$, which places them on the Efficiency Frontier determined by the data itself (assuming ignorance of the production function linking the efficient relationship between input and output). They also constitute an efficiency benchmark for the peer group, as the relationship between the variables reflects an average technical efficiency of 0.7162 (on a scale of 0 to 1 ) for the DMUs.

When using the influence of scale with decreasing returns in the relation of assets and income variables versus ROA, efficiency levels grow, and the frontier becomes closer. The companies furthest from the efficiency lines with constant and decreasing returns are neither efficient with constant returns nor with influence of scale and management. Therefore, they must review their business management to achieve better financial and competitive results.

It is suggested for future research to use the DEA methodology in the analysis of financial indicators that reflect the competitiveness of other sectors of the Colombian economy, in such a way that a comparative perspective is elaborated to determine the most competitive sectors and, in this way, orient efforts of financial investment that improves the financial indicators of the less competitive sectors and continue improving the best competitive sectors.

\section{References:}

[1] Federación Nacional de Cultivadores de Palma de Aceite - Fedepalma -. Informe de labores fondos parafiscales palmeros. 2019. Available in

http://web.fedepalma.org/sites/default/files/files/ Cenipalma/Informe-de-labores-2019/9D2Informe-Labores-FPP.pdf

[2] DANE. Boletín Técnico PIB II Trimestre 2021, 2021, pp. 1-46.

[3] Sectorial. Ficha Económica Aceites y Grasas Noviembre 2020: Exportaciones para uso en Aseo y Alimentos han Favorecido el Crecimiento Sectorial. 2021. Available in https://www.sectorial.co/articulosespeciales/item/389973-fichaecon\%C3\%B3mica-aceites-y-grasasnoviembre-2020-exportaciones-para-uso-enaseo-y-alimentos-han-favorecido-elcrecimiento-sectorial

[4] Ministerio de Agricultura y Desarrollo Rural. Cadena de palma de aceite, indicadores e instrumentos. Lecturas de Economia, 2020, pp. $1-25$.

Available 
https://sioc.minagricultura.gov.co/Palma/Docum entos/2020-03-30 Cifras Sectoriales.pdf.

[5] Federación Nacional de Cultivadores de Palma de Aceite - Fedepalma -. Informe de labores fondos parafiscales palmeros. 2019. Available in

http://web.fedepalma.org/sites/default/files/files/ Cenipalma/Informe-de-labores-2019/9D2Informe-Labores-FPP.pdf

[6] Lombana, J., \& Rozas Gutiérrez, S. Marco analítico de la competitividad: Fundamentos para el estudio de la competitividad regional. Pensamiento \& gestión, No.26, 2009, pp.1-38.

[7] Porter, M. E. The competitive advantage of nations. Competitive Intelligence Review, Vol.1, No.1, 1990, pp.14-14.

[8] Rivera Ríos, A. T., Fory Castro, S., Vargas, D. F., \& Duque Ceballos, J. L. Análisis del comportamiento de las pymes colombianas en el mercado internacional. Investigaciones en Gestión Empresarial, Ambiental y Competitividad, 2019, pp. 191-212. https://doi.org/10.35985/9789585522701.7

[9] Correa, J. A., \& Ornaghi, C. Competition \& innovation: Evidence from US patent and productivity data. The Journal of Industrial Economics, Vol.62, No.2, 2014, pp. 258-285.

[10] Porter, M. E. Industry structure and competitive strategy: Keys to profitability. Financial analysts journal, Vol.36, No.4, 1980, pp. 30-41.

[11] Barney, J. Firm resources and sustained competitive advantage. Journal of management, Vol.17, No.1, 1991, pp. 99-120.

[12] García, J. A. C., Bedoya, L. J. R., \& Ríos, C. E. C. La importancia de la planeación financiera en la elaboración de los planes de negocio y su impacto en el desarrollo empresarial. Revista de la Facultad de Ciencias Económicas: Investigación y Reflexión, Vol.18, No.1, 2010, pp. 179-194.

[13] Castro, A. M., \& Castro, J. A. M. Planning financier. Group Editorial Patria. 2014.

[14] Rojo, A. A. Valoración de empresas y gestión basada en valor. Editorial Paraninfo, 2007.

[15] Giacomozzi, A. M. (2002). Evaluación de la gestión del valor en la empresa: Propuesta de un modelo. Theoria, Vol.11, No.1, 2002, pp. 4350.

[16] Porter, M. E. Ventaja competitiva: creación y sostenimiento de un desempeño superior. Grupo editorial patria. 1990.
[17] Porter, M. E. Ventaja competitiva: creación y sostenimiento de un desempeño superior. Grupo editorial patria. 1990.

[18] Ramírez, M. H. J. Modelo de competitividad empresarial. Umbral científico, No.9, 2006, pp.115-125.

[19] Rubio, L., \& Baz, V. El poder de la competitividad. Fondo de cultura económica. 2015.

[20] De Pablo, J. C. La frontera de posibilidades de producción cuando existen bienes intermedios. $\mathrm{El}$ Trimestre Económico, Vol.37, No.146-2, 1970, pp. 405413.

[21] Savosnick, K. M. The box diagram and the production possibility curve. Ekonomisk Tidskrift, No.r3, 1958, pp. 183-197.

[22] Fuster, M. V. La Frontera de Posibilidades de Producción: eficiencia y desplazamientos. Universidad Politécnica de Valencia. 2011. Available in https://riunet.upv.es/handle/10251/13444

[23] Castro, A. M., \& Castro, J. A. M. Planning financier. Group Editorial Patria. 2014.

[24] Ramos, C. S. U., González, C. V., \& Cervantes, W. A. N. Análisis del patrón y la estabilidad del comercio de los productos agroindustriales colombianos en el marco de la Alianza del Pacífico. Una caracterización desde el RCA y RSCA entre 1995-2015. Desarrollo, innovación y tecnología en los países de la Alianza del Pacífico. Colombia: Fondo Editorial Universidad César Vallejo y Editorial Uniaugustiniana. 2021. Available in https://repositorio.ucv.edu.pe/bitstream/handle/2 0.500.12692/73823/LB_Ulloa_RB-Ulloa_RCSC\%C3\%A9sar_RJ-

Gonz\%C3\%A1lez_MB.pdf?sequence=1\#page= 134

[25] Olaya-Pizza, Y. Aporte a la sostenibilidad desde la perspectiva financiera: caso empresas Manuelita grasas y Fedepalma. 2021. Available in

https://dspaceuao.metacatalogo.com/bitstream/handle/10614/ 13355/T09993_Aporte\%20a\%201a\%20sostenibi lidad\%20desde\%20la\%20perspectiva\%20financ iera\%20-

$\% 20$ caso\%20empresas\%20Manuelita\%20Grasa s\%20y\%20Fedepalma.pdf?sequence $=1 \&$ is Allo wed $=\mathrm{y}$

[26] Vaskova, H., \& Buckova, M. Multivariate study of Raman spectral data of edible oils. WSEAS Transactions on Environment and Development, Vol.14, 2018, pp.226-232. 
[27] Charnes, A., Cooper, W. W., \& Rhodes, E. Measuring the efficiency of decision-making units. European journal of operational research, Vol.2,No.6, 1978, pp. 429-444.

[28] Coll, V., \& Blasco, O. M. Evaluación de la Eficiencia mediante el Analisis Envolvente de Datos. Introducción a los modelos básicos. 2006, pp.197. Available in http://www.eumed.net/libros-gratis/2006c/197/.

[29] Villarreal, F., \& Tohmé, F. Análisis envolvente de datos. Un caso de estudio para una universidad argentina. Estudios Gerenciales, Vol.33, 2017, pp. 302-308.

[30] Coll, V., \& Blasco, O. M. Evaluación de la Eficiencia mediante el Analisis Envolvente de Datos. Introducción a los modelos básicos. 2006, pp.28. Available in https://www.uv.es/vcoll/libros/2006_evaluacion _eficiencia_DEA.pdf

[31] Gutiérrez, D., \& Gutiérrez J. Planeación financiera y gestión del valor. Ecoe Ediciones. 2018.

[32] Superintendencia de Sociedades. Base Completa de Estados Financieros. 2019. Available in https://www.supersociedades.gov.co/delegatura _aec/Paginas/Base-completa-EF-2019.aspx

[33] Federación Nacional de Cultivadores de Palma de Aceite - Fedepalma -. Informe de labores fondos parafiscales palmeros. 2019. Available in http://web.fedepalma.org/sites/default/files/files/ Cenipalma/Informe-de-labores-2019/9D2Informe-Labores-FPP.pdf

[34] DANE. Encuesta Anual Manufacturera EAM-. 2019. Available in https://www.dane.gov.co/index.php/estadisticaspor-tema/industria/encuesta-anualmanufacturera-enam

[35] Superintendencia de Sociedades. Comportamiento de las 9.000 empresas siguientes, más grandes del sector real por ingresos operacionales (excluye las 1.000 primeras). 2020. Available in https://www.supersociedades.gov.co/delegatura _aec/estudios_financieros/Lists/sector_economi a/DispForm.aspx? $\mathrm{ID}=12 \&$ ContentTypeId $=0 \mathrm{x} 01$ 005550EFA2ADD4D841B3C9FA5427EEDE86

[36] Coelli T. J., Prasada D. S., O’Donnell C. J., Battese, G. E., An introduction to efficiency and productivity analysis. EEUU: Springer, 2005.
Contribution of Individual Authors to the Creation of a Scientific Article (Ghostwriting Policy)

Oscar Ivan Vásquez-Rivera has developed the conceptualization, visualization and writing review and editing of the research.

Carmen Alicia Diaz-Grajales has developed the methodology, data curation, formal analysis and validation of the research.

\section{Sources of Funding for Research Presented in a Scientific Article or Scientific Article Itself}

This research has been funded by General Research Office of Universidad Santiago de Cali under call No. 01-2021.

The authors thank Crimson Interactive Pvt. Ltd. (Enago) - https://www.enago.com/es/ for their assistance in manuscript translation and editing.

\section{Creative Commons Attribution License 4.0 (Attribution 4.0 International, CC BY 4.0)}

This article is published under the terms of the Creative Commons Attribution License 4.0 https://creativecommons.org/licenses/by/4.0/deed.en _US 